\title{
The Application of Omics Technologies to Study Axon Regeneration and CNS Repair [version 1; peer review: 3
}

\section{approved]}

\author{
Andrea Tedeschi (iD), Phillip G Popovich (1D)2 \\ ${ }^{1}$ Department of Neuroscience and Discovery Themes Initiative, College of Medicine, Ohio State University, Columbus, Ohio, 43210, \\ USA \\ ${ }^{2}$ Center for Brain and Spinal Cord Repair, Institute for Behavioral Medicine Research, Ohio State University, Columbus, Ohio, 43210, \\ USA
}

V1 First published: 20 Mar 2019, 8(F1000 Faculty Rev):311

https://doi.org/10.12688/f1000research.17084.1

Latest published: 20 Mar 2019, 8(F1000 Faculty Rev):311

https://doi.org/10.12688/f1000research.17084.1

\begin{abstract}
Traumatic brain and spinal cord injuries cause permanent disability. Although progress has been made in understanding the cellular and molecular mechanisms underlying the pathophysiological changes that affect both structure and function after injury to the brain or spinal cord, there are currently no cures for either condition. This may change with the development and application of multi-layer omics, new sophisticated bioinformatics tools, and cutting-edge imaging techniques. Already, these technical advances, when combined, are revealing an unprecedented number of novel cellular and molecular targets that could be manipulated alone or in combination to repair the injured central nervous system with precision. In this review, we highlight recent advances in applying these new technologies to the study of axon regeneration and rebuilding of injured neural circuitry. We then discuss the challenges ahead to translate results produced by these technologies into clinical application to help improve the lives of individuals who have a brain or spinal cord injury.
\end{abstract}

\section{Keywords}

axon regeneration, brain injury, spinal cord injury, epigenomics, transcriptomics, kinomics, phosphoproteomics, metagenomics

\section{Open Peer Review \\ Approval Status \\ 1 \\ 2 \\ 3 \\ version 1 \\ 20 Mar 2019 \\ Faculty Reviews are review articles written by the prestigious Members of Faculty Opinions. The articles are commissioned and peer reviewed before publication to ensure that the final, published version is comprehensive and accessible. The reviewers who approved the final version are listed with their names and affiliations.}

\section{Melissa R Andrews, University of}

Southampton, Southampton, UK

2. Shuxin Li, Lewis Katz School of Medicine at Temple University, Philadelphia, USA

3. Simone Di Giovanni, Imperial College London, London, UK

Any comments on the article can be found at the end of the article. 
Corresponding authors: Andrea Tedeschi (andrea.tedeschi@osumc.edu), Phillip G Popovich (phillip.popovich@osumc.edu)

Author roles: Tedeschi A: Conceptualization, Visualization, Writing - Original Draft Preparation, Writing - Review \& Editing; Popovich PG: Supervision, Writing - Review \& Editing

Competing interests: No competing interests were disclosed.

Grant information: AT is supported by the Craig H. Neilsen Foundation, the Marina Romoli Onlus Association, the Discovery Themes Initiative on Chronic Brain Injury, and The Ohio State University. PGP is supported by the National Institute of Neurological Disorders and Stroke and the Ray W. Poppleton Endowment.

The funders had no role in study design, data collection and analysis, decision to publish, or preparation of the manuscript.

Copyright: @ 2019 Tedeschi A and Popovich PG. This is an open access article distributed under the terms of the Creative Commons Attribution License, which permits unrestricted use, distribution, and reproduction in any medium, provided the original work is properly cited.

How to cite this article: Tedeschi A and Popovich PG. The Application of Omics Technologies to Study Axon Regeneration and CNS Repair [version 1; peer review: 3 approved] F1000Research 2019, 8(F1000 Faculty Rev):311

https://doi.org/10.12688/f1000research.17084.1

First published: 20 Mar 2019, 8(F1000 Faculty Rev):311 https://doi.org/10.12688/f1000research.17084.1 


\section{Introduction}

Central nervous system (CNS) trauma causes permanent disability, imposing huge economic and emotional burdens on affected family and society. No therapies exist that will effectively restore function to individuals who have an injury to the brain or spinal cord. Recovery of brain and spinal cord functions in adults might be achieved by promoting axon sprouting and regeneration, either alone or in combination with other promising approaches such as neuroprotection ${ }^{1-3}$, cell reprogramming and transplantation ${ }^{4-8}$, brain-computer interface and epidural stimulation $^{9-14}$. In the injured adult mammalian CNS, however, axon sprouting and regeneration are limited and this is due in part to both the poor intrinsic regenerative potential of adult CNS neurons ${ }^{15,16}$ and the hostile cellular and molecular environment that develops at the site of injury ${ }^{17-21}$. These are major obstacles that must be overcome to effectively promote axon regeneration, sprouting, and functional recovery after CNS trauma ${ }^{22-24}$. Recent data indicate that it is possible to overcome such barriers. For example, it is feasible to reprogram adult mammalian neurons into a growth-competent state and remove extracellular growth inhibitors to promote regrowth of axons that project to the brain and spinal $\operatorname{cord}^{16,25-32}$.

Here, we review the most recent data, emphasizing how omics technologies are improving our insight into novel mechanisms that regulate axon regeneration and also the feasibility of rebuilding functional neuronal circuits after CNS injury. We also discuss the challenges to applying these new discoveries in the clinic to maximize recovery of function.

\section{Omics approaches to study spinal cord injury}

High-throughput omics technologies, including epigenomics, transcriptomics, proteomics, metabolomics, metagenomics, immunolomics, connectomics, and lipidomics have revolutionized the way we study brain and spinal cord injury (SCI $)^{27,33-41}$ (Figure 1). When combined with high-content screening ${ }^{42-44}$, data from

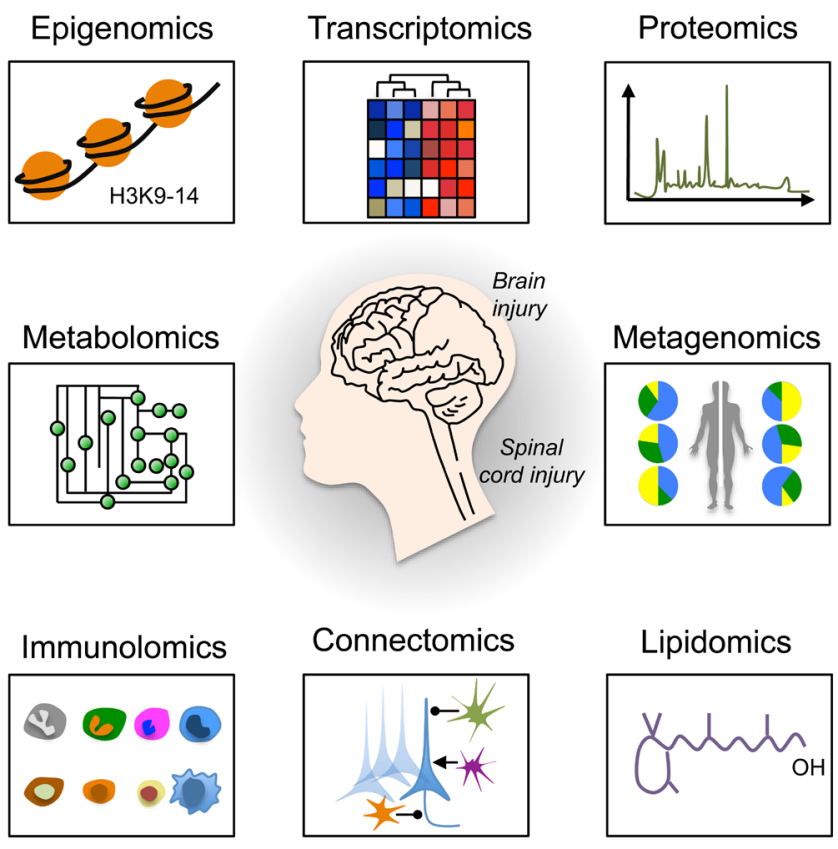

Figure 1. A multi-layer omics approach to study axon regeneration. A schematic representation of omics approaches to study axon regeneration is shown. Epigenomics studies epigenetic modifications on DNA or histone proteins that alter gene expression. DNA methylation and histone modifications are the most well-characterized epigenetic modifications. Transcriptomics examines the transcriptome that comprises all RNA transcripts (for example, mRNA and non-coding RNAs) in a given cell population. New technologies, including RNA sequencing at single-cell resolution, have been developed that allow the identification of genes and transcript variants that are actively expressed, co-expressed, or repressed. After epigenomics and transcriptomics, proteomics represents the next step in the study of any given biological system. Indeed, proteomics is the large-scale study of the proteome (for example, the set of proteins produced in an organism, system, or biological context). Protein activity is also regulated by many different factors in health and disease other than the gene expression level. Modern high-throughput technologies allow the investigation of protein location, turnover, post-translational modification, activity, and interactions in depth. Phosphoproteomics represents a branch of proteomics that focuses entirely on the identification and characterization of phosphorylated proteins. Metabolomics is the study of substrates and products (also called metabolites) of cellular metabolism and their interactions within a biological system. Each cellular activity is reflected by the presence of specific metabolites. Therefore, metabolomics represents a powerful approach to study the state and phenotype of any given biological system. Metagenomics is the genomic analysis of microbial communities from environmental and biological samples, such as the gut microbiota. Indeed, metagenomics allows the study of intestinal microbiome diversity and dysbiosis as well as its relationship between human health and disease. Immunolomics profiles cells of the immune system, antibodies, and cytokine responses in a comprehensive manner. With the advent of powerful imaging methods and molecular and genetic tools, it is now possible to create comprehensive maps of connections within the nervous system. Connectomics refers to the production and study of such connections and the molecular interactions that pair cells. One of the emerging fields of biomedical research is certainly lipidomics. Lipidomics is the large-scale study of cellular lipids at both the structural and functional levels. 
these technologies are providing unprecedented insight into how an injury to the brain or spinal cord affects the roles and interrelationships of various genes, molecules, cells, and body systems. As a result, novel targets and pathways are emerging as critical regulators of effective axon growth as well as regeneration and remodeling of both injured and spared neural circuits. In this review, we will focus on a subset of new omics data, using examples from epigenomics, transcriptomics, kinomics, phosphoproteomics, and metagenomics studies. We will then discuss how these technologies have helped identify novel biological mechanisms, such as neuronal metabolism and mitochondria transport, that contribute to axon regeneration failure.

\section{Epigenomics}

Recent data indicate that the induction of regenerative gene expression, a prerequisite for activating axon growth programs, relies partly on creating a more permissive chromatin environment in the nucleus of injured neurons ${ }^{45-51}$. Epigenomic screens of adult dorsal root ganglia (DRG) neurons injured by a peripheral nerve lesion (PNL), an experimental condition that switches DRG neurons into a regenerative-competent state, identified Tet methylcytosine dioxygenase 3 (Tet3) as a critical regulator of axon growth and regeneration. After PNL, Tet3 is upregulated along with the epigenetic mark 5-hydroxymethylcytosine $(5 \mathrm{hmC})$ in DRG neurons ${ }^{52}$. By oxidizing $5 \mathrm{hmC}$, Tet3 reverses DNA methylation. Interestingly, epigenomic mapping in DRG neurons after injury to the peripheral (regenerative) or central (no regenerative effect) projecting axons triggered differential $5 \mathrm{hmC}$ changes that were associated with distinct signaling pathways ${ }^{52}$. Nearly half of the genes that were differentially regulated after peripheral lesion contain $5 \mathrm{hmC}$ alterations $\mathrm{s}^{52}$, suggesting that $5 \mathrm{hmC}$ is a previously unrecognized mechanism that controls the regenerative potential of injured neurons.

Although transcriptional events that turn on the expression of regeneration-associated genes are recognized as important steps in the activation of cell-autonomous regeneration programs ${ }^{53}$, far less is known about how gene inactivation affects these programs. A recent study identified ubiquitin-like containing PHD ring finger 1 (UHRF1)-dependent DNA methylation as a critical epigenetic mechanism responsible for silencing expression of genes that are required to promote axon regeneration in DRG neurons ${ }^{54}$. After PNL, a decrease in miR-9 causes a transient increase in the expression of the RE1-silencing transcription factor (REST) and UHRF1 ${ }^{54}$. During embryogenesis, REST acts as master regulator by inhibiting the expression of many neuronal genes ${ }^{55}$. While a transient increase in REST primes injured DRG neurons for enhanced axon regeneration, UHRF1 interacts with DNA methyltransferases and methyl groups on histone $\mathrm{H} 3$, creating epigenetic marks that silence promoter elements of tumor suppressor genes such as the phosphatase and tensin homolog (PTEN) and REST ${ }^{54}$. Since sustained expression of REST in neurons is known to cause axon guidance defects ${ }^{56}$, UHRF1-dependent epigenetic silencing may be required to fine-tune REST activity and thus axon regeneration programs. Together, these data support the idea that neurons may need to revert to an immature or intermediate state to successfully unlock developmental programs for axon regeneration ${ }^{57-62}$.

\section{Transcriptomics}

Advanced transcriptomics analyses have identified several genes and gene networks that regulate axon regeneration success and failure ${ }^{27,34,63,64}$. However, the efficiency and success of translation of these genes have received less attention. By ribosome pull-down and metabolic isotopic labeling, a recent study analyzed gene translation and protein synthesis within the regeneration-associated program in DRG neurons. Of the proteins that undergo de novo synthesis in regenerating DRG neurons, apolipoprotein E (ApoE), which has been previously implicated in axon growth and regeneration ${ }^{65-68}$, is one of the most robustly synthesized proteins ${ }^{69}$. DRG neurons cultured in the presence of an ApoE receptor inhibitor extend shorter neurites, providing evidence that neuronal ApoE is an autocrine regulator of axon growth $^{69}$. It is likely, though speculative, that ApoE facilitates recycling of cholesterol from degenerating axons for integration into new membranes during the process of axon regeneration. Alternatively, cholesterol may be synthesized in the cell body and then efficiently delivered to the axonal compartment via anterograde transport of lipid-containing vesicles.

An unbiased genome-wide loss-of-function screen in cerebral cortical projection neurons in vitro identified Rab27b, a member of the Rab subfamily of GTPases, as a cell-autonomous factor that restricts axon regeneration ${ }^{39}$. Adult worms lacking Rab27 exhibit greater regeneration of GABA neurons. Moreover, optic nerve regeneration, raphespinal sprouting, and locomotor recovery all are enhanced in mice lacking Rab $27^{39}$. Interestingly, Caenorhabditis elegans Rab27 mutants have defects in synaptic transmission ${ }^{70}$. Given that Rab27 localizes in synaptic-rich regions and participates in the transport of synaptic vesicles ${ }^{71}$, removing or blocking Rab27 in adult neurons may promote axon regeneration by shifting the trafficking of new cell membrane from synapses to the axolemma. Indeed, new membrane insertion is necessary for axon elongation ${ }^{72}$.

Interestingly, data from an independent study show that selective exclusion of Rab11 vesicles, which are needed for axon elongation, contributes to axon regeneration failure. Rab GTPases coordinate vesicle trafficking ${ }^{73}$, thereby allowing growthpromoting cargoes to be delivered to the axon. In cultured rat cortical neurons, overexpressing Rab11 decreases axon retraction and augments new growth cone formation and enhanced axon regeneration occurs in an integrin-dependent manner ${ }^{74}$. It is likely that changes in spatiotemporal interaction between Rab GTPases and specific guanine nucleotide exchange factors contribute to diversify the role of Rab GTPases in axon growth and regeneration.

When the transcriptional landscape of mouse DRG neurons was explored in both growth-competent and -incompetent states at different developmental stages, Cacna2d2, the gene encoding the $\alpha 2 \delta 2$ subunit of voltage-gated calcium channels ${ }^{75}$, was identified as a developmental switch that limits axon growth and regeneration ${ }^{27}$ (Figure 2). Interestingly, in these neurons, the developmental transition from a growth-competent (electrically dormant) to a transmitting (electrically active) phase is associated with a marked increase in the expression of genes that control 


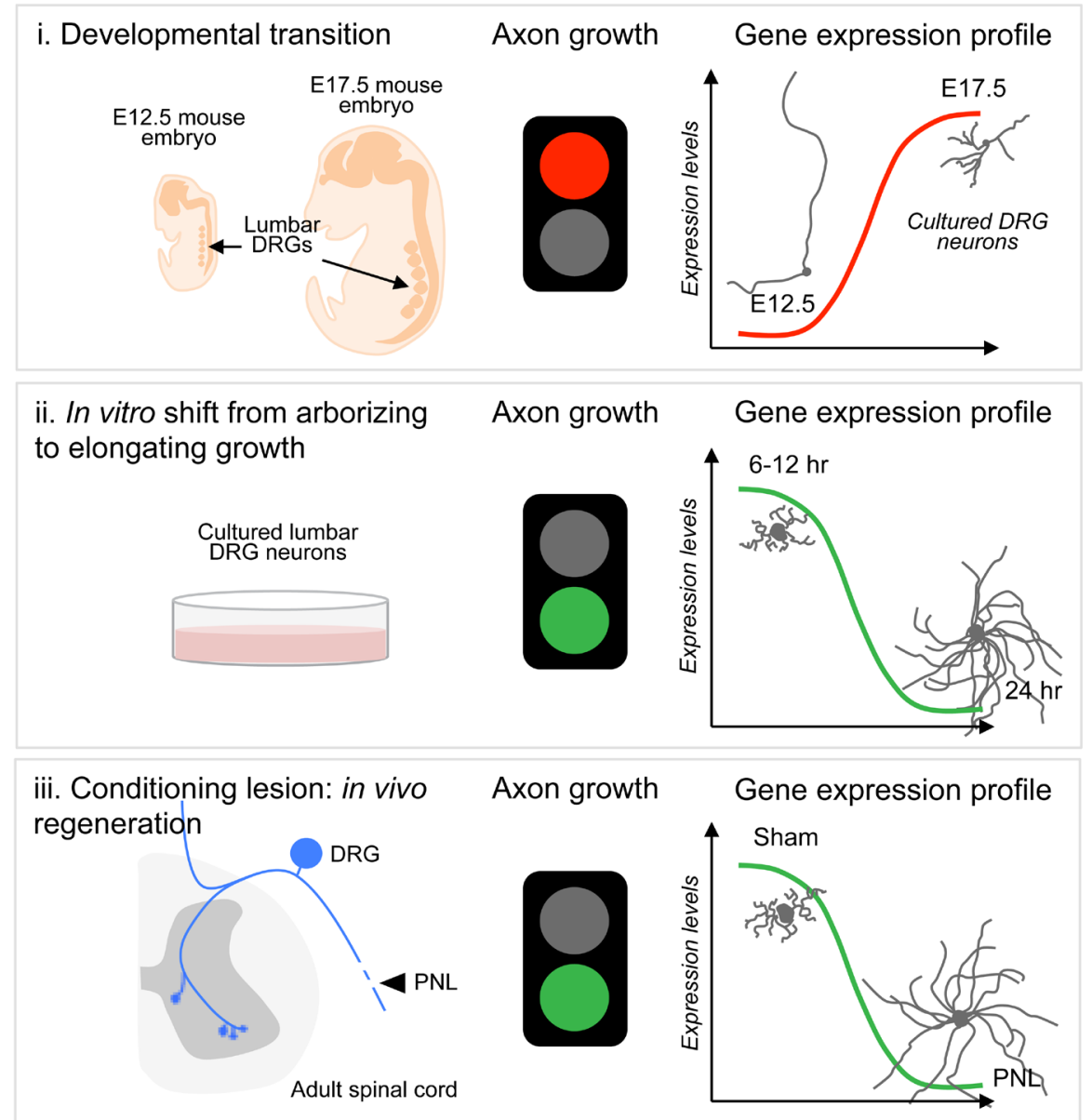

Figure 2. The transcriptional landscape of mouse dorsal root ganglia (DRG) neurons in both growth-competent and -incompetent states. DRG neurons have been instrumental in dissecting key molecular mechanisms of axon growth and regeneration failure. Whole transcriptome sequencing of DRG neurons from different stages of axon growth, including a developmental transition from axon growth to synapse formation, a shift from arborizing to elongating growth, and axon regeneration after a peripheral nerve lesion (PNL), has identified novel negative regulators of axon growth and regeneration, thus expanding the number of targets that could be manipulated for therapeutic gain. E, embryonic day.

synapse formation and synaptic transmission. Deletion or silencing of Cacna2d2 in adult DRG neurons promotes axon growth in vitro. Pharmacological blockade of $\alpha 2 \delta 2$ via systemic injection of gabapentinoids promotes regeneration of sensory axons after SCI in adult mice ${ }^{27}$. Precisely how gabapentinoids enhance axon regeneration is unknown, but a mechanistic understanding is important, especially since these drugs are often used in humans to treat various neurological disorders, including neuropathic pain. Moreover, a multi-center cohort study found that motor recovery is improved in SCI individuals receiving gabapentinoids $^{76}$. Together, these data highlight the need to consider repurposing gabapentinoids as a novel treatment for CNS repair.

During development, a discrete number of transcription factors act as master regulators of gene expression. Among others, Sox11 is highly expressed in many developing organs and its expression is turned off in adults. Whereas Soxl1 expression is not changed after CNS injury, its expression increases after peripheral injury, facilitating regeneration of injured peripheral nerves ${ }^{34,77}$. In normally non-regenerative cortical motor neurons, forcing Sox11 expression enables sprouting and regeneration of corticospinal tract (CST) axons after unilateral pyramidotomy and cervical SCI, respectively ${ }^{28}$. However, forced expression of Sox11 in CST neurons impairs, rather than improves, skilled forelimb functions ${ }^{28}$. Thus, improved axon regeneration does not necessarily predict that functional recovery also will improve. Intuitively, this makes sense since functionally significant axon regeneration is a multi-step repair process in which regenerating axons must re-establish proper synaptic connectivity in order to effectively integrate into existing or regrowing neuronal circuitry. Another study tested whether overexpression of Sox 11 or other master regulators of gene transcription can enhance regeneration of retinal ganglion cell (RGC) axons after optic nerve crush injury in adult mice. Only overexpression of Sox11, among the seven candidates tested, robustly increased RGC 
regeneration ${ }^{64}$. Interestingly, a gene ontology analysis of transcriptomics data derived from RGC neurons overexpressing Sox11 revealed that most genes that are suppressed by Sox11 are associated with synaptic transmission ${ }^{64}$, highlighting similarities with the $\alpha 2 \delta 2$ findings described above. Together, these data suggest that genetic gain-of-function manipulations can rejuvenate adult neurons, enhancing their growth potential; however, these same manipulations may inadvertently impair synaptic function in the neural circuitry.

In a search for mechanisms underlying neural plasticity, a recent study profiled the transcriptome of sprouting intact neurons isolated from mice lacking Nogo receptor 1 (for example, a receptor for myelin-associated axon growth inhibitors) after incomplete SCI. In these mice, structural plasticity and regeneration of CST axons are enhanced in various CNS injury models ${ }^{78,79}$. The authors found that the lysophosphatidic acid (LPA) signaling modulators, LPPR1 and LPAR1, are intrinsic regulators of axon growth in corticospinal neurons. More specifically, LPPR1 overexpression or LPAR1 inhibition promoted collateral sprouting of intact CST axons and enhanced functional recovery after unilateral pyramitomy in adult wild-type mice. LPA is a bioactive lipid species derived from membrane phospholipids, and among the many cellular mechanisms that LPA signaling is known to affect (including oligodendrocyte maturation, myelination, astrocyte proliferation, and inflammation), synaptic transmission is also affected by LPA ${ }^{80}$.

Single-cell RNA sequencing has emerged as a powerful technology that enables researchers to identify expression changes of thousands of genes in heterogeneous cell populations ${ }^{81,82}$. A recent study applied this technology to reveal DRG neuron heterogeneity and molecular dynamics after sciatic nerve transection ${ }^{40}$. DRG neurons can be classified into several functionally distinct subtypes with very different gene expression patterns ${ }^{83-85}$. Such heretogeneity is reflected by the fact that injury to the peripheral branch of DRG neurons is often associated with mixed responses such as pain, cell death, plasticity, and axon regeneration. After segregating DRG neurons into different subtypes, weighted gene co-expression network analysis revealed injury-responsive gene modules with distinct expression patterns among the different subtypes. Interestingly, the cell death genes-programmed cell death-2 and neuron survival-like ISL LIM homeobox-were upregulated and downregulated, respectively, in a subset of non-peptidergic nociceptor neurons 3 days after injury ${ }^{40}$. The fact that caspase- 3 was upregulated in all injured subtypes suggests that these neurons may be more susceptible to cell death and therefore not able to regenerate. Indeed, a prerequisite for axon regeneration is that injured neurons survive. Dynamic changes in gene transcription in DRG neuronal subtypes were identified by completing an analysis of the transcriptome at 3 and 7 days after axotomy. Genes related to nervous system development, axonogenesis, regulation of metabolic process, and actin cytoskeleton reorganization were gradually upregulated in large myelinated neurons ${ }^{40}$. In contrast, many genes related to learning or memory or nucleus organization were downregulated in these neurons ${ }^{40}$, further implicating gene inactivation as an important regulator of axon growth programs (see above).

\section{Kinomics}

A phenotypic screen of kinase inhibitors (that is, kinomics) combined with machine learning identified the ribosomal S6 kinase 1 (S6K1) as a negative regulator of axon regeneration in rodents $^{42}$. In C. elegans, ribosomal S6 kinase loss of function elicits new axon growth cone formation after injury and accelerates axon elongation $^{86}$. In vitro, S6K1 inhibition enhances growth of primary mouse hippocampal neurons. In vivo administration of a selective S6K1 inhibitor (for example, PF-4708671) promotes regeneration of CST axons into and beyond the lesion site in a model of cervical SCI. Functional recovery also is achieved in SCI animals treated with PF-4708671. The benefits of inhibiting S6K1, a known effector of the mammalian target of rapamycin (mTOR), conflict with data showing that mTOR is a positive regulator of axon regeneration in mammals ${ }^{16,87-89}$. Hence, new kinomics data have enriched our understanding of molecular mechanisms of axon regeneration by showing that $\mathrm{PI} 3 \mathrm{~K} / \mathrm{mTOR}$ signaling is negatively regulated by S6K1.

\section{Phosphoproteomics}

Growth cones are specialized structures that are required during axon growth and regeneration ${ }^{90}$. A better understanding of the signaling pathways that control growth cone activity may be necessary to gain control of axon growth, guidance, and regeneration as well as formation of neural circuits. Reversible protein phosphorylation is one of the most studied post-translational modifications. Phosphorylation of proline, serine, threonine, and tyrosine residues plays a crucial role in function, subcellular localization, and degradation of proteins, thus participating in various cellular processes, including signal transduction. A phosphoproteomic study of growth cone membranes isolated from postnatal day 1 rat forebrain identified 4596 phosphorylation sites from 1223 phosphoproteins ${ }^{41}$. Of these phosphorylation sites, proline phosphorylation was the most represented. Analysis of the identified phosphoproteins suggested that cytoskeletal components and signaling proteins were the most abundant ${ }^{41}$. Using a kinase-specific phosphorylation site prediction tool, the authors of this study revealed that proline phosphorylation was due to activation of the mitogen-activated protein kinase (MAPK) pathway ${ }^{41}$. Of note, coordinated activation of highly conserved MAPK pathways is required for axon growth and regeneration ${ }^{68,91-93}$. Strikingly, the most abundant phosphorylation site was an uncharacterized serine 96 of the growth-associated protein 43 (GAP-43), which is highly expressed during development and regeneration ${ }^{94-97}$. Of the different kinases involved in signal transduction, c-Jun N-terminus kinase (JNK) was responsible for numerous phosphorylated sites in the phosphoproteomic data $\operatorname{set}^{41}$.

Another interesting study applied quantitative phosphoproteomics to study changes in protein phosphorylation in primary cerebellar granule neurons plated on growth-inhibitory chondroitin sulfate proteoglycans (CSPGs). Of the differentially phosphorylated proteins, phosphorylation increased on 41 peptides and decreased on 77 in neurons exposed to CSPGs ${ }^{98}$. Cytoskeletal proteins were the top annotated category, representing 25 of the 118 phosphopeptides identified. Among these cytoskeletal proteins, 14 were of the actin family of cytoskeleton proteins. Cofilin, an actin depolymerization factor regulated by phosphorylation, 
plays an important role in growth cone behavior and neurite outgrowth $^{99}$. In neurons exposed to myelin-associated inhibitor, phosphorylation and inactivation of cofilin have been shown to be regulated via LIM kinase and slingshot phosphatase ${ }^{100}$, contributing to axon growth inhibition and regeneration failure. Similarly, overexpression of the transcription factor serum response factor enhances axon regeneration through cytoplasmic localization and cofilin-mediated reactivation of actin dynamics in growth-inert retraction bulbs ${ }^{101}$. The top three signaling pathways representing the 118 phosphopeptides were pyrimidine metabolism, p38MAPK pathway, and synaptic vesicle trafficking. Together, these results suggest that phosphoproteomics can serve as a powerful approach to unmask promising targets and signaling pathways to overcome regeneration failure in the adult CNS.

\section{Metagenomics}

Successful axon regeneration may require a detailed understanding of genetic, proteomic, metabolic, and immunologic functions that occur in the body outside the nervous system. Metagenomics is a collection of high-throughput genetic analyses of transorganismal behaviors and the biosphere. Currently, most metagenomics studies focus on non-eukaryotic microbes, especially those found in the gastrointestinal tract (that is, the "gut"), to learn how these microbes affect organs and cells throughout the body, in both health and disease. Compelling data indicate that microbial metabolites, derived from gut microbes, directly affect the function of neurons and glia in the CNS. How or whether these metabolites will affect regeneration in the injured CNS has not been explored; however, robust and lasting changes in gut microbial communities do occur after a brain injury or $\mathrm{SCI}^{102-105}$. Injury-induced change in microbial populations is a potentially novel target for regulating the structure and function of injured neurons. Indeed, the magnitude and diversity of the microbial "payload" are remarkable-unique microbial genes outnumber mammalian genes by about 150 to $1^{106}$, and an impressive number of microbial enzymes and metabolites are already known to affect the metabolism and function of mammalian cells, including those in the immune and nervous systems ${ }^{107-109}$. Thus, it is easy to speculate that metagenomic and metabolomic techniques, when applied in the context of axon regeneration models, will reveal novel roles for microbes in affecting axon regeneration.

Although recent progress in the field of axon regeneration clearly illustrates the power of using omics-based approaches to reveal novel molecular mechanisms to target for therapeutic enhancement of axon growth, we believe that a better understanding of the mechanisms controlling presynaptic biogenesis, synaptic alignment, and connectivity will be necessary to rebuild injured neural circuits in a functionally meaningful way.

\section{Neuronal metabolism and mitochondrial transport}

Promoting successful axon regeneration will likely require that we understand more than those genes and proteins that directly affect the physical structure of axons and synapses. Indeed, axon regeneration is a metabolically active, multi-step process. Omics technologies have revealed that optimal axon regeneration also depends on efficient mitochondrial transport and energy production in injured axons.

Recent evidence indicates that enhancing mitochondrial transport promotes neuron survival and axon regeneration in experimental models of axotomy in worms ${ }^{110}$ and mice $^{25,111}$ (Figure 3).

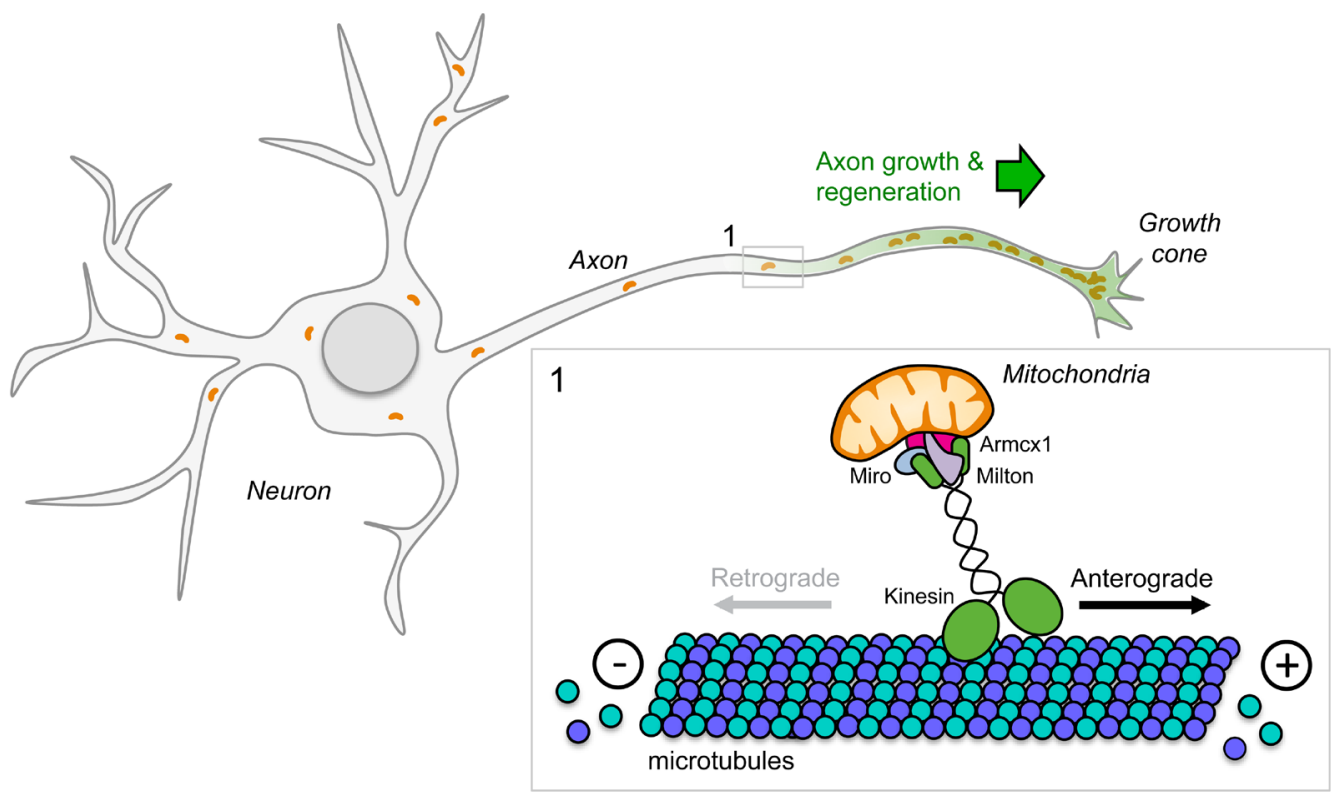

Figure 3. Mitochondria participate in axon regeneration. Mitochondria are actively transported to axons via axonal microtubules with their plus ends pointing toward the distal part and their minus ends facing the cell soma. Members of the kinesin family are responsible for mitochondria anterograde transport. Kinesin motors generate force by hydrolyzing adenosine triphosphate. Given that mitochondria provide energy for axonal functions (including active transport and membrane fusion), alteration of mitochondrial distribution along the axon leads to defects during development, maintenance, and regeneration of the nervous system. 
Anterograde mitochondrial transport requires kinesin-1 motors, whereas dynein motors control retrograde transport back to the soma $^{112-114}$. Live imaging of laser axotomized GABA motor neurons in mutant worms with an enhanced regenerative capacity has shown that mitochondrial density increases in regenerating axons and that regeneration can be enhanced further by experimentally boosting mitochondrial transport. Conversely, axon regeneration is poor in mutant worms with deficient mitochondrial transport. Mitochondrial localization to the axon is regulated in part by dual-leucine zipper kinase 1 (DLK-1) ${ }^{110}$, an evolutionarily conserved intrinsic regulator of axon growth and regeneration in worms, flies, and mice i2,115-118. $^{2}$.

Again, using the optic nerve injury model, high-throughput analysis of gene expression in RGC neurons has revealed that the armadillo repeat containing $\mathrm{x}$-linked 1 (Armcx 1 ) is a critical regulator of mitochondrial transport and plays a key role in promoting axon regeneration after optic nerve crush injury. Armcx1 localizes to mitochondria and interacts with components of the mitochondrial transport machinery, such as Miro $1^{25}$. Whereas Armcx1 overexpression enhances mitochondrial transport in mouse retinal explants and promotes RGC neuron survival and regeneration after optic nerve crush injury ${ }^{25}$, its downregulation negatively impacts axon regeneration.

Adenosine triphosphate (ATP) is the major source of cellular energy produced by mitochondria. In injured CNS axons, mitochondria acutely depolarize, causing energy deficits along the injured axons ${ }^{111}$. Recent data indicate that it is possible to reverse injury-induced energy loss and restore regenerative capacity in cultured mouse neurons. Indeed, overexpressing Miro 1 or knocking down the mitochondria-anchoring protein syntaphilin enhances mitochondrial transport and restores the energy balance in injured axons, leading to enhanced axon regeneration ${ }^{111}$.

Using proteomics and bioinformatics techniques to analyze the injury response in axotomized RGCs, Belin et al. identified 12 signaling hubs, including several neuronal intrinsic regulators of axon growth and regeneration ${ }^{33}$. The top three connected nodes are the tumor suppressor $\mathrm{p} 53^{119}, \mathrm{c}-\mathrm{Myc}^{120}$, and Rictor. The authors focused on c-myc because of its role as master transcriptional regulator of several target genes that coordinate the de novo synthesis of new lipids and proteins that are needed for axon elongation. Indeed, forced expression of c-Myc in RGCs promotes neuron survival and regeneration after optic nerve crush injury ${ }^{33}$. Although it is possible to manipulate oncogenes to achieve regenerative growth in CNS neurons in animal models, whether it is safe or prudent to do so in humans is questionable.

A recent study in C. elegans has shed some light on metabolic regulation controlling neuron repair after axotomy. O-linked $\beta$-N-acetylglucosamine (O-GlcNAc), a post-translational modification of serine and threonine residues of nuclear and cytoplasmic proteins, functions as a nutrient sensor and metabolic mediator by linking glucose metabolism to the hexosamine biosynthetic pathway. Twenty-four hours following laser axotomy in vivo, a decrease in O-GlcNAc levels promotes axon regeneration of either the anterior or posterior lateral microtubule neurons via ARK-1/AKT-1 signaling, using glycolysis as the primary source of energy ${ }^{121}$. Blocking glucose transport or inhibiting glycolysis leads to axon regeneration failure in mutant worms with decreased O-GlcNAc levels ${ }^{121}$. By contrast, increasing O-GlcNAc levels acts on mitochondrial function and enhances axon regeneration in $C$. elegans through FOXO/DAF-16-dependent mechanisms ${ }^{121}$. These seemingly contradictory results may be explained by the fact that O-GlcNAc levels drive distinct branches of the insulin pathway to promote regeneration in worms.

The liver kinase B1 (LKB1) links cellular metabolism and energy homeostasis to cell polarity and growth ${ }^{122,123}$. LKB1 phosphorylates the central metabolic sensor AMPK, whose activation regulates cholesterol, lipid, and glucose metabolism ${ }^{123}$. LKB1 overexpression in corticospinal neurons of adult mice was recently shown to promote long-distance regeneration of CST axons in experimental models of $\mathrm{SCI}^{31}$. Also, systemic overexpression of LKB1 in mice causes descending serotonergic and tyrosine hydroxylase-positive axons to regrow into caudal segments of the injured spinal cord. Mechanistically, the AMP-activated protein kinase alpha, NUAK family SNF1-like kinase 1, and extracellular signal-regulated kinase act as effectors of LKB1 to promote axon growth and regeneration ${ }^{31}$. Importantly, enhanced axon growth and regeneration in LKB1-overexpressing mice correlated with improved recovery of locomotor function ${ }^{31}$.

Together, the above examples highlight the importance of achieving efficient mitochondrial transport and energy production in injured axons to fuel axon regeneration. Whether boosting neuronal metabolism and other metabolic pathways are sufficient to repair the injured CNS requires further investigation.

\section{Conclusions}

During the last three years, novel candidates and combinatorial approaches that can promote structural plasticity, regeneration, and some degree of functional recovery have been identified $^{27,28,31,39,124-128}$. To maximize chances to achieve functional recovery, however, axon regeneration, neuronal metabolism, synapse formation, and functional connectivity need to be spatially and temporally controlled to allow the establishment, refinement, and consolidation of essential neural circuitry ${ }^{23}$. Thus far, data suggest that prolonged activation of neuron-intrinsic pathways causes defects in target innervation in several experimental injury models ${ }^{33,129,130}$. Failure to re-innervate target neurons negatively impacts functional recovery and can cause neurobehavioral abnormalities that impair normal daily activities and thus quality of life. In addition, cardiovascular disease and autonomic dysfunction have become a growing concern for individuals with $\mathrm{SCI}^{131,132}$. Thus, turning off or reducing intrinsic axon growth ability together with cardiovascular rehabilitation, activity-based training, or other facilitators may indeed facilitate synapse formation, refinement, and consolidation of functional connectivity in the injured CNS. Several lines of evidence also suggest that adult regenerating axons can be guided toward specific target areas by providing chemoattraction ${ }^{133,134}$. 
Modulating astrocyte behavior to control synapse formation and elimination represents another intriguing direction for future studies $^{135,136}$.

Several signaling pathways described above are conserved across different species. This will likely facilitate the translation of data obtained in smaller organisms and animal models to larger and more complex mammalian systems, including humans. Still, genetic variation exists within each model organism ${ }^{36,137,138}$, so exploring the robustness of treatment strategies across different genetic backgrounds, within and between species, will be prudent before embarking on randomized clinical trials in humans. Lately, despite the generation of large omics data sets, a significant amount of information remains hidden. In our opinion, validation of omics approaches with stringent criteria and additional assays is an essential step to facilitate translation of breakthrough discoveries from the laboratory into clinical practice. Although there is no optimal strategy for integrating multi-omics data sets, more integration is likely to provide the most realistic picture about true biology. It is now possible to integrate data from transcriptomics, phosphoproteomics, and metabolomics. When combined with multi-layer omics ${ }^{139-141}$, the recent development of powerful computational methods ${ }^{142-144}$, machine learning and artificial intelligence ${ }^{145,146}$ will allow data mining and extracting principles and key biological information on a broad range of normal and disease conditions. Hence, automated inference methods should allow the rapid development and testing of new hypotheses and establish potential causal relationships in large data sets. As we enter a new era of regenerative medicine, we will be able to select combinations of treatment strategies for a personalized medicine approach to aid CNS repair.

\section{Grant information}

AT is supported by the Craig H. Neilsen Foundation, the Marina Romoli Onlus Association, the Discovery Themes Initiative on Chronic Brain Injury, and The Ohio State University. PGP is supported by the National Institute of Neurological Disorders and Stroke and the Ray W. Poppleton Endowment.

The funders had no role in study design, data collection and analysis, decision to publish, or preparation of the manuscript.
1. F Fehlings MG, Vaccaro A, Wilson JR, et al.: Early versus delayed decompression for traumatic cervical spinal cord injury: Results of the Surgical Timing in Acute Spinal Cord Injury Study (STASCIS). PLOS One. 2012; 7(2): e32037.

PubMed Abstract | Publisher Full Text | Free Full Text | F1000 Recommendation

2. Fehlings MG, Wilson JR, Frankowski RF, et al:: Riluzole for the treatment of acute traumatic spinal cord injury: Rationale for and design of the NACTN Phase I clinical trial. J Neurosurg Spine. 2012; 17(1 Suppl): 151-6. PubMed Abstract | Publisher Full Text

3. F Festoff BW, Ameenuddin S, Arnold PM, et al.: Minocycline neuroprotects, reduces microgliosis, and inhibits caspase protease expression early after spinal cord injury. J Neurochem. 2006; 97(5): 1314-26. PubMed Abstract | Publisher Full Text | F1000 Recommendation

4. Su Z, Niu W, Liu ML, et al.: In vivo conversion of astrocytes to neurons in the injured adult spinal cord. Nat Commun. 2014; 5: 3338. PubMed Abstract | Publisher Full Text | Free Full Text

5. $\quad \mathrm{F}$ Kadoya K, Lu P, Nguyen K, et al:: Spinal cord reconstitution with homologous neural grafts enables robust corticospinal regeneration. Nat Med. 2016; 22(5): 479-87.

PubMed Abstract | Publisher Full Text | Free Full Text | F1000 Recommendation

6. F Lu P, Woodruff G, Wang $\mathrm{Y}$, et al.: Long-distance axonal growth from human induced pluripotent stem cells after spinal cord injury. Neuron. 2014; 83(4): 789-96.

PubMed Abstract | Publisher Full Text | Free Full Text | F1000 Recommendation

7. F Rosenzweig ES, Brock JH, Lu P, et al:: Restorative effects of human neural stem cell grafts on the primate spinal cord. Nat Med. 2018; 24(4): 484-90. PubMed Abstract | Publisher Full Text | Free Full Text | F1000 Recommendation

8. Assinck P, Duncan GJ, Hilton BJ, et al.: Cell transplantation therapy for spinal cord injury. Nat Neurosci. 2017; 20(5): 637-47. PubMed Abstract | Publisher Full Text

9. F Capogrosso M, Milekovic T, Borton D, et al:: A brain-spine interface alleviating gait deficits after spinal cord injury in primates. Nature. 2016; 539(7628): 284-8.

PubMed Abstract | Publisher Full Text | Free Full Text | F1000 Recommendation

10. $\mathrm{F}$ Harkema S, Gerasimenko $\mathrm{Y}$, Hodes J, et al.: Effect of epidural stimulation of the lumbosacral spinal cord on voluntary movement, standing, and assisted stepping after motor complete paraplegia: a case study. Lancet. 2011; 377(9781): 1938-47.

PubMed Abstract | Publisher Full Text | Free Full Text | F1000 Recommendation

11. Minev IR, Musienko P, Hirsch A, et al:: Biomaterials. Electronic dura mater for long-term multimodal neural interfaces. Science. 2015; 347(6218): 159-63. PubMed Abstract | Publisher Full Text

12. F Angeli CA, Boakye M, Morton RA, et al.: Recovery of Over-Ground Walking after Chronic Motor Complete Spinal Cord Injury. N Engl J Med. 2018; 379(13) 1244-50.

PubMed Abstract | Publisher Full Text | F1000 Recommendation

13. F Formento E, Minassian K, Wagner F, et al.: Electrical spinal cord stimulation must preserve proprioception to enable locomotion in humans with spinal cord injury. Nat Neurosci. 2018; 21(12): 1728-41.

PubMed Abstract | Publisher Full Text | Free Full Text | F1000 Recommendation

14. F Gill ML, Grahn PJ, Calvert JS, et al:: Neuromodulation of lumbosacral spinal networks enables independent stepping after complete paraplegia. Nat Med. 2018; 24(11): 1677-82.

PubMed Abstract | Publisher Full Text | F1000 Recommendation

15. Curcio M, Bradke F: Axon Regeneration in the Central Nervous System: Facing the Challenges from the Inside. Annu Rev Cell Dev Biol. 2018; 34: 495-521. PubMed Abstract | Publisher Full Text

16. $\mathrm{F}$ Liu K, Lu Y, Lee JK, et al:: PTEN deletion enhances the regenerative ability of adult corticospinal neurons. Nat Neurosci. 2010; 13(9): 1075-81. PubMed Abstract | Publisher Full Text | Free Full Text | F1000 Recommendation

17. Chen M, Geoffroy CG, Meves JM, et al.: Leucine Zipper-Bearing Kinase Is a Critical Regulator of Astrocyte Reactivity in the Adult Mammalian CNS. Cell Rep. 2018; 22(13): 3587-97.

PubMed Abstract | Publisher Full Text | Free Full Text

18. F Dias DO, Kim H, Holl D, et al.: Reducing Pericyte-Derived Scarring Promotes Recovery after Spinal Cord Injury. Cell. 2018; 173(1): 153-165.e22. PubMed Abstract | Publisher Full Text | Free Full Text | F1000 Recommendation

19. F Geoffroy CG, Zheng B: Myelin-associated inhibitors in axonal growth after CNS injury. Curr Opin Neurobiol. 2014; 27: 31-8. PubMed Abstract | Publisher Full Text | Free Full Text | F1000 Recommendation

20. Schwab ME, Strittmatter SM: Nogo limits neural plasticity and recovery from injury. Curr Opin Neurobiol. 2014; 27: 53-60. PubMed Abstract | Publisher Full Text | Free Full Text

21. Silver J, Schwab ME, Popovich PG: Central nervous system regenerative failure: Role of oligodendrocytes, astrocytes, and microglia. Cold Spring Harb Perspect Role of oligodendrocytes, $2014 ;$ 7(3): a020602. Biol. 2014; 7(3): a020602.
PubMed Abstract | Publisher Full Text | Free Full Text

22. He Z, Jin Y: Intrinsic Control of Axon Regeneration. Neuron. 2016; 90(3): 437-51. PubMed Abstract | Publisher Full Text

23. Tedeschi A, Bradke F: Spatial and temporal arrangement of neuronal intrinsic 
and extrinsic mechanisms controlling axon regeneration. Curr Opin Neurobiol. 2017; 42: 118-27.

PubMed Abstract | Publisher Full Text

24. Tran AP, Warren PM, Silver J: The Biology of Regeneration Failure and Success After Spinal Cord Injury. Physiol Rev. 2018; 98(2): 881-917. PubMed Abstract | Publisher Full Text | Free Full Text

25. F Cartoni R, Norsworthy MW, Bei F, et al.: The Mammalian-Specific Protein Armcx1 Regulates Mitochondrial Transport during Axon Regeneration. Neuron. 2016; 92(6): 1294-307.

PubMed Abstract | Publisher Full Text | Free Full Text | F1000 Recommendation

26. Luo X, Ribeiro M, Bray ER, et al.: Enhanced Transcriptional Activity and Mitochondrial Localization of STAT3 Co-induce Axon Regrowth in the Adult Central Nervous System. Cell Rep. 2016; 15(2): 398-410. PubMed Abstract | Publisher Full Text | Free Full Text

27. F Tedeschi A, Dupraz S, Laskowski CJ, et al:: The Calcium Channel Subunit Alpha2delta2 Suppresses Axon Regeneration in the Adult CNS. Neuron. 2016; 92(2): 419-34.

PubMed Abstract | Publisher Full Text | F1000 Recommendation

28. Wang Z, Reynolds A, Kirry A, et al:: Overexpression of Sox11 promotes corticospinal tract regeneration after spinal injury while interfering with functional recovery. J Neurosci. 2015; 35(7): 3139-45. PubMed Abstract | Publisher Full Text | Free Full Text

29. F Warren PM, Steiger SC, Dick TE, et al:: Rapid and robust restoration of breathing long after spinal cord injury. Nat Commun. 2018; 9(1): 4843. PubMed Abstract | Publisher Full Text | Free Full Text | F1000 Recommendation

30. F Burnside ER, De Winter F, Didangelos A, et al:: Immune-evasive gene switch enables regulated delivery of chondroitinase after spinal cord injury. Brain. 2018; 141(8): 2362-2381

PubMed Abstract | Publisher Full Text | Free Full Text | F1000 Recommendation

31. F Ohtake $\mathrm{Y}$, Sami A, Jiang $\mathrm{X}$, et al:: Promoting Axon Regeneration in Adult CNS by Targeting Liver Kinase B1. Mol Ther. 2019; 27(1): 102-17.

PubMed Abstract | Publisher Full Text | Free Full Text | F1000 Recommendation

32. O'Donovan $\mathrm{KJ}, \mathrm{Ma} \mathrm{K}, \mathrm{Guo} \mathrm{H}$, et al.: B-RAF kinase drives developmental axon growth and promotes axon regeneration in the injured mature CNS. $J$ Exp Med. 2014; 211(5): 801-14

PubMed Abstract | Publisher Full Text | Free Full Text

33. Belin S, Nawabi H, Wang C, et al.: Injury-induced decline of intrinsic regenerative ability revealed by quantitative proteomics. Neuron. 2015; $86(4)$ : 1000-14.

PubMed Abstract | Publisher Full Text | Free Full Text

34. Chandran V, Coppola G, Nawabi H, et al: A Systems-Level Analysis of the Peripheral Nerve Intrinsic Axonal Growth Program. Neuron. 2016; 89(5): 956-70. PubMed Abstract | Publisher Full Text | Free Full Text

35. Li S, Nie EH, Yin Y, et al:: GDF10 is a signal for axonal sprouting and functional recovery after stroke. Nat Neurosci. 2015; 18(12): 1737-45.

PubMed Abstract | Publisher Full Text | Free Full Text

36. Omura T, Omura K, Tedeschi A, et al:: Robust Axonal Regeneration Occurs in the Injured CAST/Ei Mouse CNS. Neuron. 2015; 86(5): 1215-27. PubMed Abstract | Publisher Full Text | Free Full Text

37. F Huebner EA, Budel S, Jiang Z, et al:: Diltiazem Promotes Regenerative Axon Growth. Mol Neurobiol. 2018.

PubMed Abstract | Publisher Full Text | F1000 Recommendation

38. F Posti JP, Dickens AM, Orešic M, et al.: Metabolomics Profiling As a Diagnostic Tool in Severe Traumatic Brain Injury. Front Neurol. 2017; 8: 398. PubMed Abstract | Publisher Full Text | Free Full Text | F1000 Recommendation

39. F Sekine Y, Lin-Moore A, Chenette DM, et al:: Functional Genome-wide Screen Identifies Pathways Restricting Central Nervous System Axonal Regeneration. Cell Rep. 2018; 23(2): 415-28.

PubMed Abstract | Publisher Full Text | Free Full Text | F1000 Recommendation

40. Hu G, Huang K, Hu Y, et al:: Single-cell RNA-seq reveals distinct injury responses in different types of DRG sensory neurons. Sci Rep. 2016; 6: 31851 PubMed Abstract | Publisher Full Text | Free Full Text

41. F Kawasaki A, Okada M, Tamada A, et al.: Growth Cone Phosphoproteomics Reveals that GAP-43 Phosphorylated by JNK Is a Marker of Axon Growth and Regeneration. iScience. 2018; 4: 190-203.

PubMed Abstract | Publisher Full Text | Free Full Text | F1000 Recommendation

42. F Al-Ali H, Ding Y, Slepak T, et al.: The mTOR Substrate S6 Kinase 1 (S6K1) Is a Negative Regulator of Axon Regeneration and a Potential Drug Target for Central Nervous System Injury. J Neurosci. 2017; 37(30): 7079-95. PublMed Abstract | Publisher Full Text | Free Full Text | F1000 Recommendation

43. Al-Ali H, Lemmon VP, Bixby JL: Phenotypic Screening of Small-Molecule Inhibitors: Implications for Therapeutic Discovery and Drug Target Development in Traumatic Brain Injury. Methods Mol Biol. 2016; 1462: 677-88. PubMed Abstract | Publisher Full Text

44. Blackmore MG, Moore DL, Smith RP, et al.: High content screening of cortical neurons identifies novel regulators of axon growth. Mol Cell Neurosci. 2010; 44(1): 43-54.

PubMed Abstract | Publisher Full Text | Free Full Text

45. F Cho Y, Sloutsky R, Naegle KM, et al:: Injury-induced HDAC5 nuclear export is essential for axon regeneration. Cell. 2013; 155(4): 894-908.

PubMed Abstract | Publisher Full Text | Free Full Text | F1000 Recommendation

46. Finelli MJ, Wong JK, Zou $\mathrm{H}$ : Epigenetic regulation of sensory axon regeneration after spinal cord injury. J Neurosci. 2013; 33(50): 19664-76. PubMed Abstract | Publisher Full Text | Free Full Text

47. F Mahar M, Cavalli V: Intrinsic mechanisms of neuronal axon regeneration. Nat Rev Neurosci. 2018; 19(6): 323-37.

PubMed Abstract | Publisher Full Text | Free Full Text | F1000 Recommendation

48. F Palmisano I, Di Giovanni S: Advances and Limitations of Current Epigenetic Studies Investigating Mammalian Axonal Regeneration. Neurotherapeutics. 2018; 15(3): 529-40.

PubMed Abstract | Publisher Full Text | Free Full Text | F1000 Recommendation

49. Puttagunta R, Tedeschi A, Sória MG, et al:: PCAF-dependent epigenetic changes promote axonal regeneration in the central nervous system. Nat Commun. 2014; 5: 3527

PubMed Abstract | Publisher Full Text

50. F Venkatesh I, Mehra V, Wang Z, et al.: Developmental Chromatin Restriction of Pro-Growth Gene Networks Acts as an Epigenetic Barrier to Axon Regeneration in Cortical Neurons. Dev Neurobiol. 2018; 78(10): 960-77. PubMed Abstract | Publisher Full Text | Free Full Text | F1000 Recommendation

51. F Weng YL, An R, Cassin J, et al:: An Intrinsic Epigenetic Barrier for Functional Axon Regeneration. Neuron. 2017; 94(2): 337-346.e6. PubMed Abstract | Publisher Full Text | Free Full Text | F1000 Recommendation

52. F Loh YE, Koemeter-Cox A, Finelli MJ, et al:: Comprehensive mapping of 5 hydroxymethylcytosine epigenetic dynamics in axon regeneration. Epigenetics. 2017; 12(2): 77-92.

PubMed Abstract | Publisher Full Text | Free Full Text | F1000 Recommendation

53. Tedeschi A: Tuning the orchestra: transcriptional pathways controlling axon regeneration. Front Mol Neurosci. 2011; 4: 60 .

PubMed Abstract | Publisher Full Text | Free Full Text

54. F Oh YM, Mahar M, Ewan EE, et al:: Epigenetic regulator UHRF1 inactivates REST and growth suppressor gene expression via DNA methylation to promot axon regeneration. Proc Natl Acad Sci U S A. 2018; 115(52): E12417-E12426. PubMed Abstract | Publisher Full Text | Free Full Text | F1000 Recommendation

55. Chen ZF, Paquette AJ, Anderson DJ: NRSF/REST is required in vivo for repression of multiple neuronal target genes during embryogenesis. Nat Genet. 1998; 20(2): 136-42.

PubMed Abstract | Publisher Full Text

56. Paquette AJ, Perez SE, Anderson DJ: Constitutive expression of the neuronrestrictive silencer factor (NRSF)/REST in differentiating neurons disrupts neuronal gene expression and causes axon pathfinding errors in vivo. Proc Natl Acad Sci U S A. 2000; 97(22): 12318-23.

PubMed Abstract | Publisher Full Text | Free Full Text

57. $\mathrm{F}$ Enes J, Langwieser $\mathrm{N}$, Ruschel $\mathrm{J}$, et al:: Electrical activity suppresses axon growth through $\mathrm{Ca}_{\mathrm{v}} 1.2$ channels in adult primary sensory neurons. Curr Biol. 2010; 20(13): 1154-64.

PubMed Abstract | Publisher Full Text | F1000 Recommendation

58. Filbin MT: Recapitulate development to promote axonal regeneration: Good or bad approach? Philos Trans R Soc Lond B Biol Sci. 2006; 361(1473): 1565-74. PubMed Abstract | Publisher Full Text | Free Full Text

59. Hilton BJ, Bradke F: Can injured adult CNS axons regenerate by recapitulating development? Development. 2017; 144(19): 3417-29.

PubMed Abstract | Publisher Full Text

60. Kaplan A, Bueno M, Hua L, et al:: Maximizing functional axon repair in the injured central nervous system: Lessons from neuronal development. Dev Dyn. 2018; 247(1): 18-23.

PubMed Abstract | Publisher Full Text

61. Lorenzana $\mathrm{AO}$, Lee JK, Mui $\mathrm{M}$, et al: A surviving intact branch stabilizes remaining axon architecture after injury as revealed by in vivo imaging in the mouse spinal cord. Neuron. 2015; 86(4): 947-54. PubMed Abstract | Publisher Full Text | Free Full Text

62. Tedeschi A, He Z: Axon regeneration: electrical silencing is a condition for regrowth. Curr Biol. 2010; 20(17): R713-4. PubMed Abstract | Publisher Full Text

63. F Fink KL, López-Giráldez F, Kim IJ, et al.: Identification of Intrinsic Axon Growth Modulators for Intact CNS Neurons after Injury. Cell Rep. 2017; 18(11): 2687-701.

PubMed Abstract | Publisher Full Text | Free Full Text | F1000 Recommendation

64. F Norsworthy MW, Bei F, Kawaguchi R, et al:: Sox11 Expression Promotes Regeneration of Some Retinal Ganglion Cell Types but Kills Others. Neuron. 2017; 94(6): 1112-1120.e4

PubMed Abstract | Publisher Full Text | Free Full Text | F1000 Recommendation

65. Comley LH, Fuller HR, Wishart TM, et al.: ApoE isoform-specific regulation of regeneration in the peripheral nervous system. Hum Mol Genet. 2011; 20(12): 2406-21.

PubMed Abstract | Publisher Full Text | Free Full Text

66. Jiménez CR, Stam FJ, Li KW, et al:: Proteomics of the injured rat sciatic nerve reveals protein expression dynamics during regeneration. Mol Cell Proteomics. 2005; 4(2): 120-32.

PubMed Abstract | Publisher Full Text 
67. Li FQ, Fowler KA, Neil JE, et al.: An apolipoprotein E-mimetic stimulates axona regeneration and remyelination after peripheral nerve injury. $J$ Pharmacol Exp Ther. 2010; 334(1): 106-15.

PubMed Abstract | Publisher Full Text | Free Full Text

68. F Yin C, Guo ZD, He ZZ, et al.: Apolipoprotein E Affects In Vitro Axonal Growth and Regeneration via the MAPK Signaling Pathway. Cell Transplant. 2018; 963689718808736 PubMed Abstract | Publisher Full Text | F1000 Recommendation

69. F Rozenbaum M, Rajman M, Rishal I, et al:: Translatome Regulation in Neuronal Injury and Axon Regrowth. eNeuro. 2018; 5(2): pii: ENEURO.0276-17.2018. PubMed Abstract | Publisher Full Text | Free Full Text | F1000 Recommendation

70. Mahoney TR, Liu Q, Itoh T, et al:: Regulation of synaptic transmission by RAB3 and RAB-27 in Caenorhabditis elegans. Mol Biol Cell. 2006; 17(6): 2617-25. PubMed Abstract | Publisher Full Text | Free Full Text

71. Pavlos NJ, Grønborg M, Riedel D, et al:: Quantitative analysis of synaptic vesicle Rabs uncovers distinct yet overlapping roles for Rab3a and Rab27b in $\mathbf{C a}^{2+}$ triggered exocytosis. J Neurosci. 2010; 30(40): 13441-53. PubMed Abstract | Publisher Full Text

72. F Quiroga S, Bisbal M, Cáceres A: Regulation of plasma membrane expansion during axon formation. Dev Neurobiol. 2018; 78(3): 170-80.

PubMed Abstract | Publisher Full Text | F1000 Recommendation

73. Stenmark H: Rab GTPases as coordinators of vesicle traffic. Nat Rev Mol Cell Biol. 2009; 10(8): 513-25.

PubMed Abstract | Publisher Full Text

74. F Koseki H, Donegá M, Lam BY, et al:: Selective rab11 transport and the intrinsic regenerative ability of CNS axons. eLife. 2017; 6: pii: e26956. PubMed Abstract | Publisher Full Text | Free Full Text | F1000 Recommendation

75. Dolphin AC: Calcium channel auxiliary $\alpha_{2} \delta$ and $\beta$ subunits: Trafficking and one step beyond. Nat Rev Neurosci. 2012; 13(8): 542-55. PubMed Abstract | Publisher Full Text

76. Warner FM, Cragg JJ, Jutzeler CR, et al.: Early Administration of Gabapentinoids Improves Motor Recovery after Human Spinal Cord Injury. Cell Rep. 2017; 18(7): 1614-8.

PubMed Abstract | Publisher Full Text

77. Jankowski MP, Mcllwrath SL, Jing X, et al.: Sox11 transcription factor modulates peripheral nerve regeneration in adult mice. Brain Res. 2009; 1256: 43-54. PubMed Abstract | Publisher Full Text | Free Full Text

78. Fink KL, Strittmatter SM, Cafferty WB: Comprehensive Corticospinal Labeling with mu-crystallin Transgene Reveals Axon Regeneration after Spinal Cord Trauma in ngr 1 $^{--}$Mice. J Neurosci. 2015; 35(46): 15403-18. PubMed Abstract | Publisher Full Text | Free Full Text

79. F Meves JM, Geoffroy CG, Kim ND, et al:: Oligodendrocytic but not neuronal Nogo restricts corticospinal axon sprouting after CNS injury. Exp Neurol. 2018; 309: 32-43.

PubMed Abstract | Publisher Full Text | Free Full Text | F1000 Recommendation

80. Yung YC, Stoddard NC, Mirendil H, et al:: Lysophosphatidic Acid signaling in the nervous system. Neuron. 2015; 85(4): 669-82.

PubMed Abstract | Publisher Full Text | Free Full Text

81. Tabula Muris Consortium; Overall coordination; Logistical coordination, et al.: Single-cell transcriptomics of $\mathbf{2 0}$ mouse organs creates a Tabula Muris. Nature. 2018; 562(7727): 367-72.

PubMed Abstract | Publisher Full Text

82. Häring $\mathrm{M}$, Zeisel $\mathrm{A}$, Hochgerner $\mathrm{H}$, et al:: Neuronal atlas of the dorsal horn defines its architecture and links sensory input to transcriptional cell types. Nat Neurosci. 2018; 21(6): 869-80.

PubMed Abstract | Publisher Full Text

83. Chiu IM, Barrett LB, Williams EK, et al:: Transcriptional profiling at whole population and single cell levels reveals somatosensory neuron molecular diversity. eLife. 2014; 3: e04660

PubMed Abstract | Publisher Full Text | Free Full Text

84. Li CL, Li KC, Wu D, et al:: Somatosensory neuron types identified by highcoverage single-cell RNA-sequencing and functional heterogeneity. Cell Res. 2016; 26(1): 83-102.

PubMed Abstract | Publisher Full Text | Free Full Text

85. F Usoskin D, Furlan A, Islam S, et al:: Unbiased classification of sensory neuron types by large-scale single-cell RNA sequencing. Nat Neurosci. 2015; 18(1): 145-53

PubMed Abstract | Publisher Full Text | F1000 Recommendation

86. Hubert $\mathrm{T}, \mathrm{Wu} Z$, Chisholm $\mathrm{AD}$, et al:: $\mathbf{S} \mathbf{6}$ kinase inhibits intrinsic axon regeneration capacity via AMP kinase in Caenorhabditis elegans. $J$ Neurosci. 2014; 34(3): 758-63.

PubMed Abstract | Publisher Full Text | Free Full Text

87. Christie KJ, Webber CA, Martinez JA, et al:: PTEN inhibition to facilitate intrinsic regenerative outgrowth of adult peripheral axons. J Neurosci. 2010; 30(27) 9306-15.

PubMed Abstract | Publisher Full Text

88. F Park KK, Liu K, Hu Y, et al:: Promoting axon regeneration in the adult CNS by modulation of the PTEN/mTOR pathway. Science. 2008; 322(5903): 963-6. PubMed Abstract | Publisher Full Text | Free Full Text | F1000 Recommendation
89. Yang $L$, Miao $L$, Liang $F$, et al.: The mTORC1 effectors S6K1 and 4E-BP play different roles in CNS axon regeneration. Nat Commun. 2014; 5: 5416 PubMed Abstract | Publisher Full Text | Free Full Text

90. Bradke F, Fawcett JW, Spira ME: Assembly of a new growth cone after axotomy: The precursor to axon regeneration. Nat Rev Neurosci. 2012; 13(3): 183-93. PubMed Abstract | Publisher Full Text

91. Widmann C, Gibson S, Jarpe MB, et al.: Mitogen-activated protein kinase: Conservation of a three-kinase module from yeast to human. Physiol Rev. 1999; 79(1): 143-80. PubMed Abstract | Publisher Full Text

92. $\mathrm{F}$ Hammarlund M, Nix P, Hauth L, et al:: Axon Regeneration Requires a Conserved MAP Kinase Pathway. Science. 2009; 323(5915): 802-6. PubMed Abstract | Publisher Full Text | Free Full Text | F1000 Recommendation

93. Nix $\mathrm{P}$, Hisamoto $\mathrm{N}$, Matsumoto $\mathrm{K}$, et al:: Axon regeneration requires coordinate activation of p38 and JNK MAPK pathways. Proc Natl Acad Sci U S A. 2011; 108(26): 10738-43.

PubMed Abstract | Publisher Full Text | Free Full Text

94. Basi GS, Jacobson RD, Virág I, et al.: Primary structure and transcriptiona regulation of GAP-43, a protein associated with nerve growth. Cell. 1987; 49(6): 785-91.

PubMed Abstract | Publisher Full Text

95. Benowitz LI, Perrone-Bizzozero NI, Finklestein SP, et al:: Localization of the growth-associated phosphoprotein GAP-43 (B-50, F1) in the human cerebral cortex. J Neurosci. 1989; 9(3): 990-5.

PubMed Abstract | Publisher Full Text

96. Nakamura F, Strittmatter P, Strittmatter SM: GAP-43 Augmentation of G ProteinMediated Signal Transduction Is Regulated by Both Phosphorylation and Palmitoylation. J Neurochem. 1998; 70(3): 983-92. PubMed Abstract | Publisher Full Text

97. Strittmatter SM, Igarashi M, Fishman MC: GAP-43 amino terminal peptides modulate growth cone morphology and neurite outgrowth. J Neurosci. 1994; 14(9): 5503-13.

PubMed Abstract | Publisher Full Text

98. Yu P, Pisitkun T, Wang G, et al.: Global analysis of neuronal phosphoproteome regulation by chondroitin sulfate proteoglycans. PLoS One. 2013; 8(3): e59285. PubMed Abstract | Publisher Full Text | Free Full Text

99. Meberg PJ, Bamburg JR: Increase in Neurite Outgrowth Mediated by Overexpression of Actin Depolymerizing Factor. J Neurosci. 2000; 20(7): 2459-69.

PubMed Abstract | Publisher Full Text

100. Hsieh SHK, Ferraro GB, Fournier AE: Myelin-associated inhibitors regulate cofilin phosphorylation and neuronal inhibition through LIM kinase and Slingshot phosphatase. J Neurosci. 2006; 26(3): 1006-15.

PubMed Abstract | Publisher Full Text

101. Stern S, Haverkamp S, Sinske D, et al.: The transcription factor serum response factor stimulates axon regeneration through cytoplasmic localization and cofilin interaction. J Neurosci. 2013; 33(48): 18836-48. PubMed Abstract | Publisher Full Text

102. F Gungor B, Adiguzel E, Gursel I, et al:: Intestinal Microbiota in Patients with Spinal Cord Injury. PLoS One. 2016; 11(1): e0145878. PubMed Abstract | Publisher Full Text | Free Full Text | F1000 Recommendation

103. Kigerl KA, Hall JC, Wang L, et al:: Gut dysbiosis impairs recovery after spinal cord injury. J Exp Med. 2016; 213(12): 2603-20. PubMed Abstract | Publisher Full Text | Free Full Text

104. $\mathrm{F}$ Ma EL, Smith $\mathrm{AD}$, Desai N, et al.: Bidirectional brain-gut interactions and chronic pathological changes after traumatic brain injury in mice. Brain Behav Immun. 2017; 66: 56-69.

PubMed Abstract | Publisher Full Text | Free Full Text | F1000 Recommendation

105. F O'Connor G, Jeffrey E, Madorma D, et al: Investigation of Microbiota Alterations and Intestinal Inflammation Post-Spinal Cord Injury in Rat Model. J Neurotrauma. 2018; 35(18): 2159-66.

PubMed Abstract | Publisher Full Text | Free Full Text | F1000 Recommendation

106. Vázquez-Baeza Y, Callewaert C, Debelius J, et al:: Impacts of the Human Gut Microbiome on Therapeutics. Annu Rev Pharmacol Toxicol. 2018; 58: 253-70. PubMed Abstract | Publisher Full Text

107. El Aidy S, Dinan TG, Cryan JF: Gut Microbiota: The Conductor in the Orchestra of Immune-Neuroendocrine Communication. Clin Ther. 2015; 37(5): 954-67. PubMed Abstract | Publisher Full Text

108. Hill DA, Artis D: Intestinal bacteria and the regulation of immune cell homeostasis. Annu Rev Immunol. 2010; 28: 623-67. PubMed Abstract | Publisher Full Text | Free Full Text

109. Ochoa-Repáraz J, Mielcarz DW, Begum-Haque S, et al.: Gut, bugs, and brain: role of commensal bacteria in the control of central nervous system disease. Ann Neurol. 2011; 69(2): 240-7.

PubMed Abstract | Publisher Full Text

110. F Han SM, Baig HS, Hammarlund M: Mitochondria Localize to Injured Axons to Support Regeneration. Neuron. 2016; 92(6): 1308-23. PubMed Abstract | Publisher Full Text | Free Full Text | F1000 Recommendation

111. $\mathrm{F}$ Zhou B, Yu P, Lin MY, et al:: Facilitation of axon regeneration by enhancing 
mitochondrial transport and rescuing energy deficits. J Cell Biol. 2016; 214(1): 103-19.

PubMed Abstract | Publisher Full Text | Free Full Text | F1000 Recommendation

112. F Glater EE, Megeath LJ, Stowers RS, et al:: Axonal transport of mitochondria requires milton to recruit kinesin heavy chain and is light chain independent. J Cell Biol. 2006; 173(4): 545-57.

PubMed Abstract | Publisher Full Text | Free Full Text | F1000 Recommendation

113. Lin MY, Sheng ZH: Regulation of mitochondrial transport in neurons. Exp Cell Res. 2015; 334(1): 35-44.

PubMed Abstract | Publisher Full Text | Free Full Text

114. Saxton WM, Hollenbeck PJ: The axonal transport of mitochondria. J Cell Sci. 2012; 125(Pt 9): 2095-104. PubMed Abstract | Publisher Full Text | Free Full Text

115. Hao Y, Frey E, Yoon C, et al:: An evolutionarily conserved mechanism for cAMP elicited axonal regeneration involves direct activation of the dual leucine zipper kinase DLK. eLife. 2016; 5: pii: e14048. PubMed Abstract | Publisher Full Text | Free Full Text

116. Shin JE, Cho Y, Beirowski B, et al:: Dual leucine zipper kinase is required for retrograde injury signaling and axonal regeneration. Neuron. 2012; 74(6): 1015-22.

PubMed Abstract | Publisher Full Text | Free Full Text

117. Tedeschi A, Bradke F: The DLK signalling pathway--a double-edged sword in neural development and regeneration. EMBO Rep. 2013; 14(7): 605-14. PubMed Abstract | Publisher Full Text | Free Full Text

118. Yan $\mathrm{D}, \mathrm{Wu} Z$, Chisholm AD, et al:: The DLK-1 kinase promotes mRNA stability and local translation in $\mathrm{C}$. elegans synapses and axon regeneration. Cell. 2009; 138(5): 1005-18.

PubMed Abstract | Publisher Full Text | Free Full Text

119. Tedeschi A, Di Giovanni S: The non-apoptotic role of p53 in neuronal biology: enlightening the dark side of the moon. EMBO Rep. 2009; 10(6): 576-83. PubMed Abstract | Publisher Full Text | Free Full Text

120. Stine ZE, Walton ZE, Altman BJ, et al.: MYC, Metabolism, and Cancer. Cancer Discov. 2015; 5(10): 1024-39.

PubMed Abstract | Publisher Full Text | Free Full Text

121. F Taub DG, Awal MR, Gabel CV: O-GIcNAc Signaling Orchestrates the Regenerative Response to Neuronal Injury in Caenorhabditis elegans. Cell Rep. 2018; 24(8): 1931-1938.e3.

PubMed Abstract | Publisher Full Text | F1000 Recommendation

122. Hardie DG: AMPK: positive and negative regulation, and its role in whole-body energy homeostasis. Curr Opin Cell Biol. 2015; 33: 1-7. PubMed Abstract | Publisher Full Text

123. Shackelford DB, Shaw RJ: The LKB1-AMPK pathway: metabolism and growth control in tumour suppression. Nat Rev Cancer. 2009; 9(8): 563-75. PubMed Abstract | Publisher Full Text | Free Full Text

124. Geoffroy CG, Lorenzana AO, Kwan JP, et al:: Effects of PTEN and Nogo Codeletion on Corticospinal Axon Sprouting and Regeneration in Mice. J Neurosci. 2015; 35(16): 6413-28. PubMed Abstract | Publisher Full Text | Free Full Text

125. Gobrecht $\mathrm{P}$, Andreadaki A, Diekmann $\mathrm{H}$, et al: Promotion of Functional Nerve Regeneration by Inhibition of Microtubule Detyrosination. J Neurosci. 2016; 36(14): 3890-902. PubMed Abstract | Publisher Full Text

126. F Liu Y, Wang X, Li W, et al:: A Sensitized IGF1 Treatment Restores Corticospinal Axon-Dependent Functions. Neuron. 2017; 95(4): 817-833.e4. PubMed Abstract | Publisher Full Text | Free Full Text | F1000 Recommendation

127. F Ruschel J, Hellal F, Flynn KC, et al.: Axonal regeneration. Systemic administration of epothilone $B$ promotes axon regeneration after spinal cord injury. Science. 2015; 348(6232): 347-52.

PubMed Abstract | Publisher Full Text | Free Full Text | F1000 Recommendation

128. F Wang XW, Li Q, Liu CM, et al.: Lin28 Signaling Supports Mammalian PNS and CNS Axon Regeneration. Cell Rep. 2018; 24(10): 2540-2552.e6. PubMed Abstract | Publisher Full Text | Free Full Text | F1000 Recommendation

129. F Carlin D, Golden JP, Mogha A, et al:: Deletion of Tsc2 in Nociceptors Reduces Target Innervation, Ion Channel Expression, and Sensitivity to Heat.
eNeuro. 2018; 5(2): pii: ENEURO.0436-17.2018.

PubMed Abstract | Publisher Full Text | Free Full Text | F1000 Recommendation

130. Pernet $\mathrm{V}$, Joly $\mathrm{S}$, Dalkara $\mathrm{D}$, et al.: Long-distance axonal regeneration induced by CNTF gene transfer is impaired by axonal misguidance in the injured adult optic nerve. Neurobiol Dis. 2013; 51: 202-13.

PubMed Abstract | Publisher Full Text

131. Myers J, Lee M, Kiratli J: Cardiovascular disease in spinal cord injury: an overview of prevalence, risk, evaluation, and management. Am J Phys Med Rehabil. 2007; 86(2): 142-52.

PublMed Abstract | Publisher Full Text

132. Prüss $\mathrm{H}$, Tedeschi $\mathrm{A}$, Thiriot $\mathrm{A}$, et al:: Spinal cord injury-induced immunodeficiency is mediated by a sympathetic-neuroendocrine adrenal reflex. Nat Neurosci. 2017; 20(11): 1549-59.

PubMed Abstract | Publisher Full Text

133. F Alto LT, Havton LA, Conner JM, et al:: Chemotropic guidance facilitates axonal regeneration and synapse formation after spinal cord injury. Nat Neurosci. 2009; 12(9): 1106-13.

PubMed Abstract | Publisher Full Text | Free Full Text | F1000 Recommendation

134. F Anderson MA, O'Shea TM, Burda JE, et al:: Required growth facilitators propel axon regeneration across complete spinal cord injury. Nature. 2018; 561(7723): 396-400.

PubMed Abstract | Publisher Full Text | Free Full Text | F1000 Recommendation

135. Chung WS, Allen NJ, Eroglu C: Astrocytes Control Synapse Formation, Function, and Elimination. Cold Spring Harb Perspect Biol. 2015; 7(9): a020370. PubMed Abstract | Publisher Full Text | Free Full Text

136. Faissner A, Pyka M, Geissler M, et al.: Contributions of astrocytes to synapse formation and maturation - Potential functions of the perisynaptic extracellular matrix. Brain Res Rev. 2010; 63(1-2): 26-38.

PubMed Abstract | Publisher Full Text

137. Tedeschi A, Omura $\mathrm{T}$, Costigan M: CNS repair and axon regeneration: Using genetic variation to determine mechanisms. Exp Neurol. 2017; 287(Pt 3): 409-22. PubMed Abstract | Publisher Full Text | Free Full Text

138. Lisi V, Singh B, Giroux M, et al:: Enhanced Neuronal Regeneration in the CAST/ Ei Mouse Strain Is Linked to Expression of Differentiation Markers after Injury. Cell Rep. 2017; 20(5): 1136-47. PubMed Abstract | Publisher Full Text | Free Full Tex

139. $\mathrm{F}$ Bakker OB, Aguirre-Gamboa R, Sanna S, et al:: Integration of multi-omics data and deep phenotyping enables prediction of cytokine responses. Nat Immunol. 2018; 19(7): 776-86.

PublMed Abstract | Publisher Full Text | Free Full Text | F1000 Recommendation

140. Hasin Y, Seldin M, Lusis A: Multi-omics approaches to disease. Genome Biol. 2017; 18(1): 83 PubMed Abstract | Publisher Full Text | Free Full Text

141. Kawata K, Hatano A, Yugi K et al:: Trans-omic Analysis Reveals Selective Responses to Induced and Basal Insulin across Signaling, Transcriptional, and Metabolic Networks. iScience. 2018; 7: 212-29. PubMed Abstract | Publisher Full Text | Free Full Text

142. Huang S, Chaudhary K, Garmire LX: More Is Better: Recent Progress in MultiOmics Data Integration Methods. Front Genet. 2017; 8: 84 PubMed Abstract | Publisher Full Text | Free Full Text

143. Kohl M, Megger DA, Trippler M, et al:: A practical data processing workflow for multi-OMICS projects. Biochim Biophys Acta. 2014; 1844(1 Pt A): 52-62. PubMed Abstract | Publisher Full Text

144. F Rohart $F$, Gautier B, Singh A, et al:: mixOmics: An R package for 'omics feature selection and multiple data integration. PLoS Comput Biol. 2017; 13(11): e1005752.

PubMed Abstract | Publisher Full Text | Free Full Text | F1000 Recommendation

145. Chaudhary K, Poirion OB, Lu L, et al: Deep Learning-Based Multi-Omics Integration Robustly Predicts Survival in Liver Cancer. Clin Cancer Res. 2018; 24(6): 1248-59.

PubMed Abstract | Publisher Full Text | Free Full Text

146. Costello Z, Martin HG: A machine learning approach to predict metabolic pathway dynamics from time-series multiomics data. NPJ Syst Biol Appl. 2018; 4: 19 .

PubMed Abstract | Publisher Full Text | Free Full Text 


\section{Open Peer Review}

\section{Current Peer Review Status:}

\section{Editorial Note on the Review Process}

Faculty Reviews are review articles written by the prestigious Members of Faculty Opinions. The articles are commissioned and peer reviewed before publication to ensure that the final, published version is comprehensive and accessible. The reviewers who approved the final version are listed with their names and affiliations.

\section{The reviewers who approved this article are:}

\section{Version 1}

\section{Simone Di Giovanni}

Department of Medicine, Imperial College London, London, UK

Competing Interests: No competing interests were disclosed.

\section{Shuxin Li}

Shriners Hospitals Pediatric Research Center and Department of Anatomy and Cell Biology, Lewis Katz School of Medicine at Temple University, Philadelphia, PA, USA

Competing Interests: No competing interests were disclosed.

\section{Melissa R Andrews}

Biological Sciences, University of Southampton, Southampton, UK

Competing Interests: No competing interests were disclosed.

The benefits of publishing with F1000Research:

- Your article is published within days, with no editorial bias

- You can publish traditional articles, null/negative results, case reports, data notes and more

- The peer review process is transparent and collaborative

- Your article is indexed in PubMed after passing peer review

- Dedicated customer support at every stage

For pre-submission enquiries, contact research@f1000.com 